\title{
Uji Efektifitas Ekstrak Etanol Daun Annona Muricata Terhadap Sel Kanker Payudara Mcf-7
}

\section{The Effect of Annona Muricata's Leaf Ethanolic Extract Against the Breast Cancer Cell Line Mcf-7}

Azarya Angelina Ibrahim ${ }^{1,2}$. Willy Sandhika ${ }^{3}$. Vicky Sumarki Budipramana ${ }^{4}$

${ }^{1}$ Program Studi Imunologi, Sekolah Pascasarjana Universitas Airlangga

${ }^{3}$ Departemen Patologi Anatomi, Fakultas Kedokteran Universitas Airlangga

${ }^{4}$ Departemen Ilmu Bedah, Fakultas Kedokteran Universitas Airlangga

(Email: acha.ibrahim@gmail.com; willysandh@gmail.com; vickysbudi@gmail.com)

\begin{abstract}
ABSTRAK
Kanker payudara adalah tumor ganas yang terbentuk dari sel-sel payudara yang tumbuh dan berkembang tanpa terkendali. Annona muricata Linn atau Graviola telah digunakan sebagai obat tradisional untuk menangani berbagai jenis penyakit, salah satunya adalah kanker. Tujuan penelitian adalah untuk melihat pengaruh ekstrak etanol daun A. muricata terhadap proliferasi cell line MCF-7. Jenis penelitian adalah eksperimental dimana cell line kanker payudara MCF-7 diberi ekstrak etanol daun A. muricata dengan konsentrasi 200, 125, 62.5, 31.25, 15.625 $\mu \mathrm{g} / \mathrm{ml}$ kemudian diinkubasi 24 jam. Setelah itu dilakukan uji sitotoksik menggunakan metode MTT assay, kemudian dihitung viabilitas sel dan nilai IC $_{50}$. Hasil yang didapat adalah nilai $\mathrm{IC}_{50}$ sebesar $117,87 \mu \mathrm{g} / \mathrm{ml}$ dan viabilitas sel berkurang sesuai dengan bertambah atau berkurangnya konsentrasi dengan tingkat korelasi kuat $\left(\mathrm{R}^{2}=0.834\right)$. Dapat disimpulkan bahwa ekstrak etanol daun $A$. muricata dapat digunakan sebagai pilihan terapi anti-kanker alami untuk kanker payudara.
\end{abstract}

Kata Kunci: Kanker payudara, Ekstrak etanol daun Annona muricata, MCF-7, MTT assay

\section{ABSTRACT}

Breast cancer is a malignant tumor formed from the growing breast cells and developed uncontrollably. Annona muricata Linn or Graviola, a member of the Annonaceae family, has been used as a traditional medicine to treat various types of diseases, which one of them is cancer. The purpose of this research is to analyze the effect of the leaf ethanolic extract of A. muricata on the proliferation of breast cancer cell line MCF-7. The type of this research is an experimental research which breast cancer cell line MCF-7 will be treated with the leaf ethanolic extract of A. muricata at a concentration of 200, 125, 62.5, 31.25, $15.625 \mu \mathrm{g} / \mathrm{ml}$, and incubated for 24 hours. Subsequently, cytotoxic test is performed by using MTT assay method to calculate the cell viability and $I_{50}$. The results obtained are the value of $I_{50}$ at $117.87 \mu \mathrm{g} / \mathrm{ml}$ and the decreasing of the breast cancer cell viability following the changes of concentration, with a strong correlation $\left(R^{2}=0.834\right)$. In conclusion, the leaf ethanolic extract of A. muricata can be used as a natural anti-cancer therapy for breast cancer.

Keywords: Breast Cancer, Leaf Ethanolic Extract Of Annona Muricata, MCF-7, MTT Assay 


\section{PENDAHULUAN}

Saat ini salah satu jenis kanker yaitu kanker payudara menjadi salah satu jenis kanker yang sangat menakutkan bagi perempuan di seluruh dunia termasuk Indonesia. Kanker payudara adalah tumor ganas yang terbentuk dari sel-sel payudara yang tumbuh dan berkembang tanpa terkendali sehingga dapat menyebar ke jaringan atau organ yang berada dekat dengan payudara atau ke bagian tubuh lainnya (Kemenkes, 2016). Kanker payudara adalah kanker paling umum kedua di dunia dan merupakan kanker yang paling sering di antara perempuan dengan perkiraan 1,67 juta kasus kanker baru yang didiagnosis pada tahun 2012 (25\% dari semua kanker). Kasus kanker payudara lebih banyak terjadi di daerah kurang berkembang (883.000 kasus) dibandingkan dengan daerah yang lebih maju (794.000 kasus).

Dari 10 jenis kanker terbanyak di RS Kanker Dharmais Jakarta, kanker payudara menduduki urutan pertama sampai dengan tahun 2016, bahkan terjadi peningkatan jumlah kasus tiap tahunnya sehingga proporsi kanker payudara sekitar $40 \%$ dari seluruh kasus kanker di rumah sakit tersebut. Menurut data GLOBOCAN, International Agency for Research on Cancer (IARC), tahun 2012 diketahui bahwa kanker payudara merupakan penyakit kanker dengan persentase kasus baru (setelah dikontrol oleh umur) tertinggi, yaitu sebesar 43,3\% dan persentase kematian (setelah dikontrol oleh umur) akibat kanker payudara sebesar 12,9\% (Kemenkes, 2016). Diantara berbagai masalah utama dalam terapi kanker payudara, faktanya adalah sebagian besar pasien yang menderita kanker payudara tidak mampu membayar biaya terapi yang sangat tinggi. Selain itu, ditemukan juga bahwa lebih dari $70 \%$ kematian akibat kanker terjadi pada orang-orang yang memiliki penghasilan rendah hingga menengah (Minari dan Okeke, 2014).

Meskipun berbagai obat-obatan telah banyak ditemukan untuk menurunkan pertumbuhan tumor, terdapat suatu kebutuhan yang mendesak untuk mencari alternatif lain dalam menanggulangi berbagai keterbatasan dalam menangani kanker payudara. Dengan kemajuan teknologi dalam bidang kesehatan, banyak tanaman obat-obatan yang dijadikan sebagai objek penelitian 
Azarya A. Ibrahim: Efek Anti-Kanker Ekstrak Etanol Daun Annona muricata...

dimana kandungan metabolit/bioaktif sekundernya berpotensi menjadi antikanker. Annona muricata Linn atau Graviola yang merupakan anggota family Annonaceae telah digunakan sebagai obat tradisional untuk menangani berbagai jenis penyakit seperti demam, rematik, kanker dan juga sebagai sedatif, insektisida dan imunosupresif. Studi fitokimia telah banyak dilakukan pada berbagai bagian A. muricata dan hingga saat ini, 212 metabolit sekunder telah berhasil diisolasi dan diidentifikasi seperti acetogenin, alkaloid, fenol, dan megastigmanes. Dari berbagai penelitian yang telah dilakukan, daun A. muricata merupakan sumber yang kaya akan Annonaceous acetogenins (AA) (Wahab et al, 2018). Penelitian intensif menunjukkan kandungan kimiawi dalam daun dan biji yaitu acetogenin yang menjelaskan efek terapeutik yang dimilikinya (Syed Najmuddin, Romli, Hamid, Alitheen, \& Abd Rahman, 2016). Ekstrak A. Muricata memiliki aktivitas sitotoksik terhadap beberapa cell line kanker pada manusia atau mamalia lainnya. Annonaceous acetogenins (AA) merupakan salah satu bahan kimia aktif yang terdapat dalam daun sirsak. AA dapat menyebabkan terhentinya siklus sel yang sangat dibutuhkan dalam proliferasi sel kanker. AA menghentikan siklus sel pada fase G1 dan menurunkan jumlah sel pada fase S dengan cara menurunkan ekspresi cyclin D1, suatu protein regulator penting dalam siklus sel (Jacobo-Herrera et al., 2019). Cell line merupakan elemen kunci untuk diagnosis molekuler pada kanker payudara karena cell line dapat digunakan dalam berbagai aspek dalam penelitian laboratorium khususnya sebagai model studi in vitro pada penelitian kanker. Pada kanker payudara, sel MCF-7 adalah sel yang paling banyak digunakan dalam penelitian eksperimental mengenai sel kanker payudara yang positif estrogen receptor (ER) (Comsa et al, 2015).

Berdasarkan data sebelumnya, maka peneliti ingin menguji aktivitas anti kanker ekstrak etanol daun Annona muricata pada cell line kanker payudara MCF-7. Berdasarkan data yang diperoleh nantinya, diharapkan agar dapat mendukung penelitian-penelitian selanjutnya mengenai efek anti kanker yang dimiliki oleh daun Annona muricata.

\section{METODE}


Jenis penelitian ini adalah penelitian eksperimental untuk melihat pengaruh pemberian ekstrak etanol daun sirsak pada cell line MCF-7. Tujuan penelitian ini adalah untuk melihat nilai $\mathrm{IC}_{50}$ dari ekstrak etanol daun sirsak dan mengukur tingkat korelasi antara viabilitas sel dan konsentrasi ekstrak. Sampel daun sirsak didapatkan dari UPT Laboratorium Herbal Materia Medica Batu pada bulan Maret 2019. Sampel kemudian dikeringkan menggunakan oven (Binder) dengan suhu $45{ }^{\circ} \mathrm{C}$. Daun yang sudah kering dibuat menjadi serbuk menggunakan blender (Miyako) dan direndam dalam etanol 96\% selama 24 jam sambil diaduk berkali-kali. Setelah itu dilakukan penyaringan maserat menggunakan kertas saring. Ekstrak cair kemudian diuapkan sampai 3 kali dan setelah itu diuapkan lagi sampai mengental.

Cell line kanker payudara yaitu MCF-7 didapatkan dari Cancer Chemoprevention Research Center Universitas Gadjah Mada (CCRC UGM, Yogyakarta). MCF-7 dikultur dalam media RPMI dan diberikan 10\% Fetal Bovine Serum (FBS) dan 1\% Penisilin/Streptomisin. Sel kemudian diinkubasi di dalam inkubator $\mathrm{CO}_{2}$. Sel dipasase setelah mencapai tingkat konfluensi $80 \%$. Setelah itu sel MCF-7 dimasukkan ke dalam 96 well dan dibagi menjadi 7 kelompok yaitu kontrol media (hanya media saja), kontrol sel (sel dan media), kelompok dosis ekstrak etanol daun sirsak $(200 \mu 1,125 \mu 1,62.5 \mu 1,31.25 \mu 1$, $15.625 \mu \mathrm{l})$. Sebanyak $100 \mu \mathrm{l}$ ekstrak etanol daun Annona muricata ditambahkan ke dalam sumuran dan diinkubasi selama 24 jam. Selanjutnya dilakukan uji sitotoksik menggunakan metode MTT. Prinsip dari metode MTT adalah terjadinya reduksi garam kuning tetrazolium MTT (3-[4,5-dimethiltiazol-2-yl]-2,5 difeniltetrazolim bromid) oleh sistem reduktase. Penambahan reagen stopper akan melarutkan kristal berwarna yang kemudian diukur absorbansinya menggunakan ELISA reader. Tujuan pemeriksaan ini adalah untuk melihat viabilitas sel atau proliferasi sel. Potensi sitotoksik ekstrak daun sirsak ini dinilai berdasarkan IC $_{50}$ yang didapat. Sebanyak $100 \mu$ l larutan MTT kemudian ditambahkan ke dalam setiap sumuran dan diinkubasi dalam inkubator $\mathrm{CO}_{2}$ selama $3-6$ jam. Setelah itu larutan MTT dikeluarkan dari sumuran dan ditambahkan stopper SDS 10\% $100 \mu \mathrm{l}$ 
Azarya A. Ibrahim: Efek Anti-Kanker Ekstrak Etanol Daun Annona muricata...

kemudian diinkubasi biasa tanpa $\mathrm{CO}_{2}$ selama 24 jam. Akhirnya, sumuran dibaca

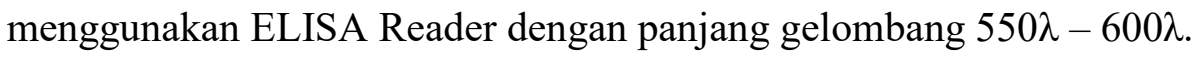

Pengujian dilakukan masing-masing dengan 3 ulangan kontrol sel dan kontrol media. Dengan menggunakan data absorban yang diperoleh dari pengukuran, dapat ditentukan persentase sel yang terhambat. Hubungan antara konsentrasi larutan uji dengan daya hambatan sel dapat ditampilkan dalam bentuk grafik untuk menentukan nilai $\mathrm{IC}_{50}$ dengan microsoft excell (regresi linear dari log konsentrasi) atau SPSS untuk melihat parameter $\mathrm{r}$ pada persamaan regresi linear dengan syarat $\mathrm{r}$ lebih besar dari $\mathrm{r}$ tabel. Nilai $\mathrm{IC}_{50}$ diperoleh dengan terlebih dahulu membuat persamaan garis yang menghubungkan antara \% inhibisi terhadap konsentrasi larutan uji masing-masing sampel (1000, 500, 200, 125, dan $62.5 \mu \mathrm{g} / \mathrm{ml}$ ). Persamaan regresi linear yang diperoleh dalam bentuk persamaan $\mathrm{y}=$ $\mathrm{a}+\mathrm{bx}$ digunakan untuk mencari nilai $\mathrm{IC}_{50}$ (inhibitor concentration $50 \%$ ) dari masing-masing sampel dengan menyatakan nilai y sebesar 50 dan nilai x yang akan diperoleh dari $\mathrm{IC}_{50}$.

\section{HASIL}

Sebanyak $1 \mathrm{~kg}$ daun Annona muricata menghasilkan ekstrak etanol 96 gram. Perhitungan \%viabilitas sel setelah pemberian ekstrak etanol Annona muricata menggunakan rumus:

$$
\% \text { Viabilitas }=\frac{(\text { absorbansi perlakuan-absorbansi kontrol media) }}{(\text { absorbansi kontrol sel-absorbansi kontrol media) }} \times 100 \%
$$

Hasil perhitungan \% viabilitas sel setelah pemberian ekstrak etanol daun Annona muricata diperoleh grafik yang dapat dilihat pada Gambar 1. 


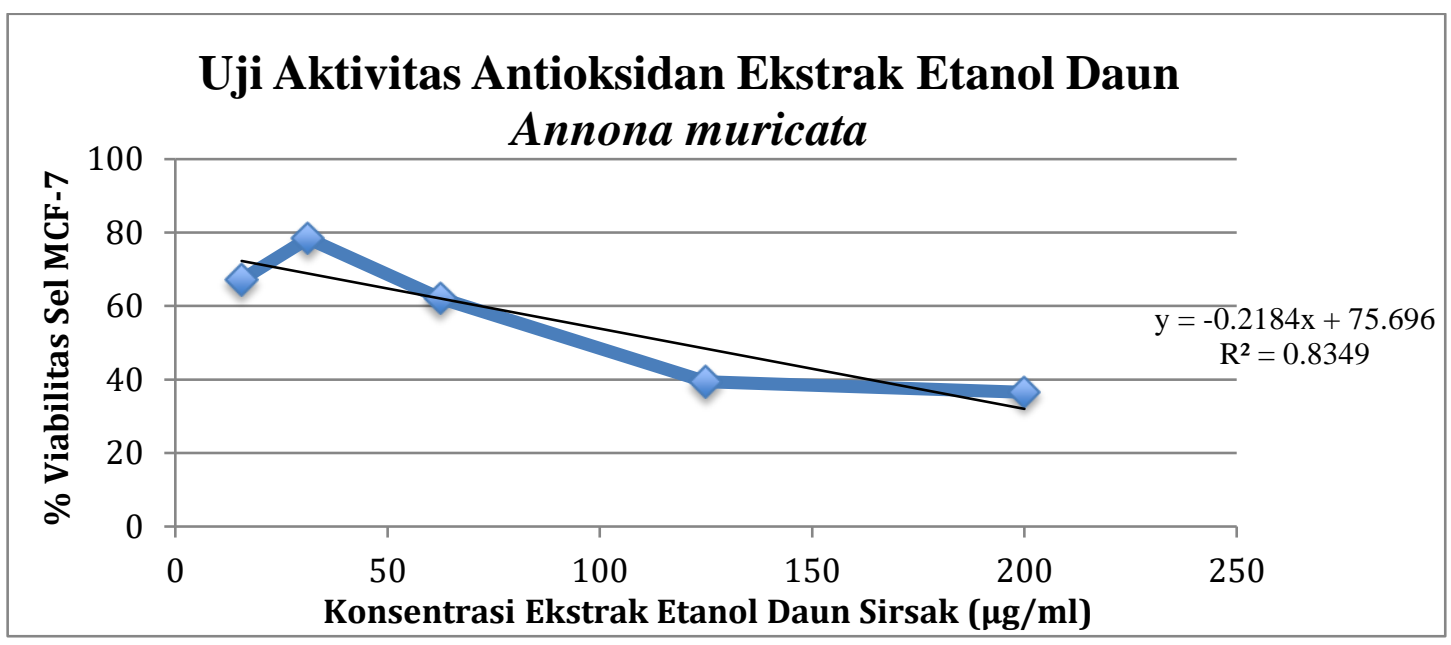

Gambar 1. Pengujian Aktivitas Antioksidan Ekstrak Etanol Daun Annona Muricata

Berdasarkan Gambar 1, diperoleh nilai y $=-0,2184+75,696$. Berdasarkan nilai y pada pengujian aktivitas antioksidan ekstrak etanol daun Annona muricata, maka dapat diperoleh nilai $\mathrm{IC}_{50}$ dengan mengganti nilai y dengan angka 50. Perhitungan nilai IC $_{50}$ dijabarkan sebagai berikut: $y=-0.2184 x+75.69650=-0.2184 x+$ $75.696 \rightarrow \mathrm{x}=\frac{50-75.696}{0.2184} \rightarrow \mathrm{x}=117.87 \mu \mathrm{g} / \mathrm{ml}$

\section{PEMBAHASAN}

Korelasi antara jumlah ekstrak yang ditambahkan dengan absorbansi sel ditemukan kuat $\left(\mathrm{R}^{2}=0.834\right)$ sehingga dapat disimpulkan bahwa terdapat pengaruh antara konsentrasi dengan absorbansi atau viabilitas sel. Berdasarkan kurva hubungan antara konsentrasi ekstrak dengan persen viabilitas sel yang diujikan dengan ekstrak etanol daun sirsak dapat dilihat secara umum bahwa semakin tinggi konsentrasi ekstrak yang diberikan, semakin rendah persentase viabilitas sel MCF-7, yang dapat diartikan bahwa ekstrak etanol daun Annona muricata memiliki aktivitas sitotoksik terhadap cell line kanker payudara MCF-7. Dalam literatur disebutkan bahwa ekstrak dapat dikatakan memiliki aktivitas sitotoksik jika nilai IC 50 kurang dari $1000 \mu \mathrm{g} / \mathrm{ml}$ setelah 24 jam kontak dengan sel kanker (Arifianti, Sukardiman, Studiawan, Rakhmawati, \& Megawati, 2014). Nilai IC $_{50}$ dari ekstrak etanol daun Annona muricata berada pada konsentrasi 
Azarya A. Ibrahim: Efek Anti-Kanker Ekstrak Etanol Daun Annona muricata...

$117,87 \mu \mathrm{g} / \mathrm{ml}$ dan dengan demikian dapat dikatakan bahwa ekstrak etanol daun Annona muricata dianggap bersifat toksik, khususnya terhadap sel kanker payudara MCF-7. Sifat toksis ini, diduga dapat disebabkan oleh adanya senyawa antioksidan pada ekstrak etanol dari daun A. Muricata yang berperan dalam mengurangi jumlah sel kanker.

Hal ini sesuai dengan penelitian sebelumnya yang memperlihatkan bahwa daun tanaman A. muricata mengandung berbagai senyawa kimia antara lain alkaloid, acetogenin, dan fenol seperti quercetin dan asam galik. Dari berbagai komponen bioaktif yang dimiliki oleh sirsak, annonaceous acetogenins (AA) memberikan efek anti-proliferatif dan anti-kanker. Selain itu, acetogenin menunjukkan aktivitas antioksidan dan dianggap sebagai obat masa depan untuk penanganan penyakit kronis yang disebabkan oleh stres oksidatif (Kim et al., 2018). Pada penelitian yang dilakukan oleh Sulistyoningrum et al (2017) menunjukkan adanya perubahan histoligikal pada jaringan kanker payudara dan penurunan indeks proliferatif kanker pada tikus yang diinduksi DMBA (Sulistyoningrum et al., 2017). AA menghambat kompleks I mitokondria karena struktur bis-THF yang dimilikinya. Mono-THF AA pembawa rantai alkil yang menghubungkan bagian lakton dengan kelompok THF merupakan inhibitor nonkompetitif dari kompleks I dalam rantai pernapasan yang kemudian menuntun pada blokade oksidasi fosforilasi dan penurunan produksi ATP. Inhibisi tersebut melibatkan kelompok jalur yang bermacam-macam yang dapat menginduksi kematian sel, yaitu apoptosis dan autofagi atau beraksi pada jaringan metabolik lainnya sebagai inhibitor enzim laktat dehidrogenase A, sebagai anti-oksidan atau dengan menghentikan siklus sel. AA meningkatkan apoptosis pada sel kanker dengan mengaktivasi jalur caspase 3 dan Bax (Jacobo-Herrera et al., 2019). Selain itu, AA akan menghambat NADH oksidase yang berhubungan dengan ubiquinone pada membran plasma sel kanker sehingga menyebabkan apoptosis (Coria-Téllez et al, 2018). Namun, penelitian lebih lanjut diperlukan untuk mengetahui bagaimana mekanisme ekstrak etanol daun sirsak dalam menghambat proliferasi dan meningkatkan apoptosis pada sel kanker payudara. 
Jurnal Manajemen Kesehatan Yayasan RS.Dr.Soetomo Vol.6 No.1 April 2020 :

\section{SIMPULAN}

Ekstrak etanol daun Annona muricata dapat menghambat pertumbuhan sel kanker MCF-7 secara in vitro menggunakan pemeriksaan MTT assay dengan $\mathrm{IC}_{50}$ sebesar 117,87 $\mu \mathrm{g} / \mathrm{ml}$. Ekstrak etanol daun A. muricata efektif dalam menghambat

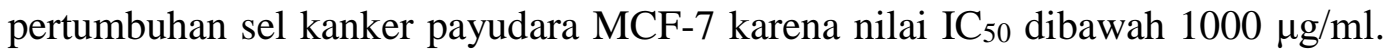
Senyawa turunan dari ekstrak daun A. muricata dapat digunakan sebagai bahan alternatif alami yang murah untuk pengobatan kanker payudara.

\section{UCAPAN TERIMA KASIH}

Terima kasih banyak kami sampaikan kepada Dr. Theresia Indah Budhy S. Drg., M.Kes sebagai kepala bagian prodi imunologi sekolah pascasarjana Universitas Airlangga atas dukungan yang diberikan selama penelitian dilaksanakan.

\section{DAFTAR PUSTAKA}

Arifianti, L., Sukardiman, Studiawan, H., Rakhmawati, \& Megawati, L. (2014). Uji Aktivitas Ekstrak Biji Sirsak (Jurnal Farmasi Dan Ilmu Kefarmasian Indonesia, 1(2), 63-66.

Comsa, Ş., Cimpean, A. M., \& Raica, M. (2015). The Story of MCF-7: Anticancer research. Anticancer Research, 35(6), 3147-3154. Retrieved from http://ar.iiarjournals.org/content/35/6/3147.long

Coria-Téllez, A. V., Montalvo-Gónzalez, E., Yahia, E. M., \& Obledo-Vázquez, E. N. (2018). Annona muricata: A comprehensive review on its traditional medicinal uses, phytochemicals, pharmacological activities, mechanisms of action and toxicity. Arabian Journal of Chemistry, 11(5), 662-691. https://doi.org/10.1016/j.arabjc.2016.01.004

Jacobo-Herrera, N., Pérez-Plasencia, C., Castro-Torres, V. A., Martínez-Vázquez, M., González-Esquinca, A. R., \& Zentella-Dehesa, A. (2019). Selective Acetogenins and Their Potential as Anticancer Agents. Frontiers in Pharmacology, 10(July), 1-12. https://doi.org/10.3389/fphar.2019.00783

Kemenkes. (2016). Oktober 2016 Bulan Peduli Kanker Payudara. Infodatin.

Kim, J. Y., Dao, T. T. P., Song, K., Park, S. B., Jang, H., Park, M. K., ... Kim, Y. S. (2018). Annona muricata Leaf Extract Triggered Intrinsic Apoptotic Pathway to Attenuate Cancerous Features of Triple Negative Breast Cancer MDA-MB-231 Cells. Evidence-Based Complementary and Alternative Medicine, 2018. https://doi.org/10.1155/2018/7972916

Minari, J. B., \& Okeke, U. (2014). Chemopreventive effect of Annona muricata on DMBA-induced cell proliferation in the breast tissues of female albino mice. Egyptian Journal of Medical Human Genetics, 15(4), 327-334. https://doi.org/10.1016/j.ejmhg.2014.05.001 
Azarya A. Ibrahim: Efek Anti-Kanker Ekstrak Etanol Daun Annona muricata...

Sulistyoningrum, E., Rachmani, E. P. N., Baroroh, H. N., \& Rujito, L. (2017). Annona muricata leaves extract reduce proliferative indexes and improve histological changes in Rat's breast cancer. Journal of Applied Pharmaceutical Science, 7(1), 149-155. https://doi.org/10.7324/JAPS.2017.70120

Syed Najmuddin, S. U. F., Romli, M. F., Hamid, M., Alitheen, N. B., \& Abd Rahman, N. M. A. N. (2016). Anti-cancer effect of Annona Muricata Linn Leaves Crude Extract (AMCE) on breast cancer cell line. $B M C$ Complementary and Alternative Medicine, 16(1), 1-20. https://doi.org/10.1186/s12906-016-1290-y

Wahab, S. M. A., Jantan, I., Haque, M. A., \& Arshad, L. (2018). Exploring the leaves of Annona muricata L. as a source of potential anti-inflammatory and anticancer agents. Frontiers in Pharmacology, 9(JUN), 1-20. https://doi.org/10.3389/fphar.2018.00661

\begin{tabular}{|l|l|}
\hline Submission & 2 Januari 2020 \\
\hline Review & 2 Januari 2020 \\
\hline Accept & 29 Maret 2020 \\
\hline Publish & 23 April 2020 \\
\hline DOI & 10.29241 jmk.v\%vi\%i.289 \\
\hline Sinta Level & 4 ( Empat) \\
\hline
\end{tabular}

